\title{
Occupational injuries and the "student syndrome" (or procrastination) on a large construction project
}

\section{Lesiones ocupacionales y el "sindrome del estudiante" (o procrastinación) en un gran proyecto de construcción}

\author{
Fredy-E Niño-Espejo ${ }^{1,2}$; Alvaro-J Idrovo ${ }^{3}$
}

Suggested citation: Niño-Espejo FE, Idrovo AJ. Occupational injuries and the "student syndrome" (or procrastination) on a large construction project. Rev Univ Ind Santander Salud. 2019; 51(4): 329-332. doi: http://dx.doi.org/10.18273/revsal.v51n4-2019006 (c) (1)

\begin{abstract}
Introduction: There is a higher occurrence of injuries on the first working days of the week, and between 13:00 and 17:00 hours. An association between some special dates and changes in the occurrence of deaths or diseases have been described in different countries and regions. Our hypothesis was that completing contractual obligations with a company may become triggers that increase the occurrence of occupational injuries. Methods: Injury records were analyzed and consolidated monthly payroll reports (from January 2012 to September 2013) for personnel operations who worked in companies that were involved in a megaproject to build a road in Colombia. This analysis reports a possible association between dates of financially important contractual milestones and a higher occurrence of occupational injuries. One-tailed binomial tests were used to compare the occurrence of injuries one and two months before and one month after four deadlines, corresponding to $14,3,1$ and $1 \%$ of the overall budget, respectively. Results: The highest occurrence of injuries was observed during the month before the deadline corresponding to $14 \%$ of the budget $(p=0.07)$. Discussion: Contractual milestones could act as distal determinant whereas human errors are proximal determinants of injuries.
\end{abstract}

Keywords: Injuries; Time; Construction; Occupational health; Safety.

\section{Resumen}

Introducción: Hay una mayor incidencia de lesiones en los primeros días hábiles de la semana, y entre las 13:00 y las 17:00 horas. Se ha descrito una asociación entre algunas fechas especiales y cambios en la ocurrencia de muertes o enfermedades en diferentes países y regiones. Nuestra hipótesis fue que el cumplimiento de las obligaciones contractuales de una empresa puede convertirse en un desencadenante que aumenta la ocurrencia

1. Universidad del Rosario. Bogotá, Colombia.

2. Diades Ingeniería Ltda. Bogotá, Colombia.

3. Universidad Industrial de Santander. Bucaramanga, Colombia

Correspondence: Alvaro J. Idrovo. Carrera 32 29-31. Phone number: +57 7634400, ext. 3123 E-mail: idrovoaj@yahoo.com.mx.pr

AJI is editor of Salud UIS. During the evaluation process of this article, he did not become part of the committee that made decisions about the review process, and did not know the reviewers. This sought to ensure transparency in the editorial process. 
de lesiones laborales. Métodos: Nosotros analizamos los registros de lesiones e informes de nómina mensuales consolidados (de enero de 2012 a septiembre de 2013) para el personal que trabajaba en empresas que participaron en un megaproyecto para construir una carretera en Colombia. Este análisis informa una posible asociación entre las fechas de hitos contractuales financieramente importantes y una mayor ocurrencia de lesiones laborales. Pruebas binomiales de una cola se usaron para comparar la ocurrencia de lesiones uno y dos meses antes vs un mes después de cuatro fechas límite, correspondientes al 14, 3, 1 y 1\% del presupuesto general, respectivamente. Resultados: La mayor incidencia de lesiones se observó durante el mes anterior a la fecha límite correspondiente al $14 \%$ del presupuesto $(p=0,07)$. Discusión: Los hitos contractuales podrían actuar como determinantes distales, mientras que los errores humanos son determinantes proximales de las lesiones.

Palabras clave: Lesiones; Tiempo; Construcción; Salud ocupacional; Seguridad.

\section{Introduction}

Time is the least studied variable in occupational injuries, except for cases such as natural disasters, where before-after analysis is mandatory ${ }^{1}$. Some previous studies have been associated with a greater occurrence of injuries at the first working days of the week regardless of culture. In the US, Sundays and Mondays are the days with a higher incidence of occupational injuries, especially among men workers ${ }^{2}$, whereas in Iran the higher occurrences are on Saturdays (first workday in this country) and Sundays $^{3}$. In China, the higher incidences of fatal injuries occur on Mondays and in July and August ${ }^{4}$. In Australia and Spain between 14:00 and 16:00 and between 13:00 and 17:00, respectively, are the hours with more occupational fatalities, suggesting a "lunch effect" ${ }^{5}$.

These few findings contrast with several studies that have explored the association between the occurrence of health outcomes and specific dates. Mortality and acute morbidity could change their occurrence on a daily, weekly or another temporal basis when social events are celebrated. For instance, mortality increases just after New Year's Day, Thanksgiving, Christmas, and individuals' birthdays ${ }^{6}$. In Sweden, the day before starting tax derogations mortality decreases ${ }^{7}$, whereas in Taiwan during the "ghost month" ( August) the occurrence of unintentional drowning deaths is lower than in other months ${ }^{8}$. A sociocultural epidemiology study in Mexico reported overall mortality increased during Christmas Day and All Saints' Day, and during Candlemas Day among women, and New Year's New Year's Day among men'. To watch stressful soccer matches have been associated with higher incidences of acute cardiovascular events among German fans ${ }^{10}$, and acute alcohol intoxication increase on the day prior public holidays and special social events among Australians ${ }^{11}$. Suicide is more frequent in New Year's Day, Mother's Day, Mexican Independence Day, and
Christmas among Mexicans ${ }^{12}$. Unfortunately, this type of findings is not consistent around the world, which suggests a specific sociocultural effect in each context.

One possible explanation of some of these associations is related to the economic incentives provided by certain dates ${ }^{6}$. For this reason, deadlines for completing contractual obligations with a company may become triggers that increase the occurrence of occupational injuries, as is the case with other outcomes. In the area of project management, "student syndrome" explains the human behavior of working at different intensities during the work process, with a relatively slow (regulated) pace the majority of the time while leaving most of the activities until last minute, just before the deadline $^{13}$. Psychology calls this procrastination ${ }^{14}$, which suggests that it is a phenomenon with sociocultural roots and is inherent to individuals. In this analysis we explored the potential association between contractual obligations and increase in the occurrence of occupational injuries.

\section{Material and methods}

To explore this hypothesis, we analyzed injury records and consolidated monthly payroll reports (from January 2012 to September 2013) for personnel operations who worked in five companies that were involved in a megaproject to build a road in a highly mountainous region in Colombia. This project included a main tunnel of $8.6 \mathrm{~km}$ long, 24 secondary tunnels, 24 bridges, and complementary works. This secondary data analysis was approved by the School of Medicine and Health Sciences of the Universidad del Rosario, Bogotá, Colombia. Since our hypothesis that occur during the month after deadline < occurrence before the deadline, we used one-tailed binomial tests to compare the occurrence of injuries one and two months before and one month after four deadlines. Numerators used were the crude occurrence of occupational injuries, and the total of workers in each month were denominators. The 
contract goals were to be met in March and July of 2012 and February and June of 2013, corresponding to 14, 3, 1 and $1 \%$ of the overall budget, respectively.

\section{Results}

Three hundred forty-two injuries occurred during the study period. The most frequent injuries were falls, hits with objects and entrapments of upper limbs among construction assistants, operators and drivers. Figure 1 presents the results of the analysis, which shows the highest occurrence of injuries during the month before the deadline corresponding to $14 \%$ of the budget. No significant differences were observed in other deadlines.

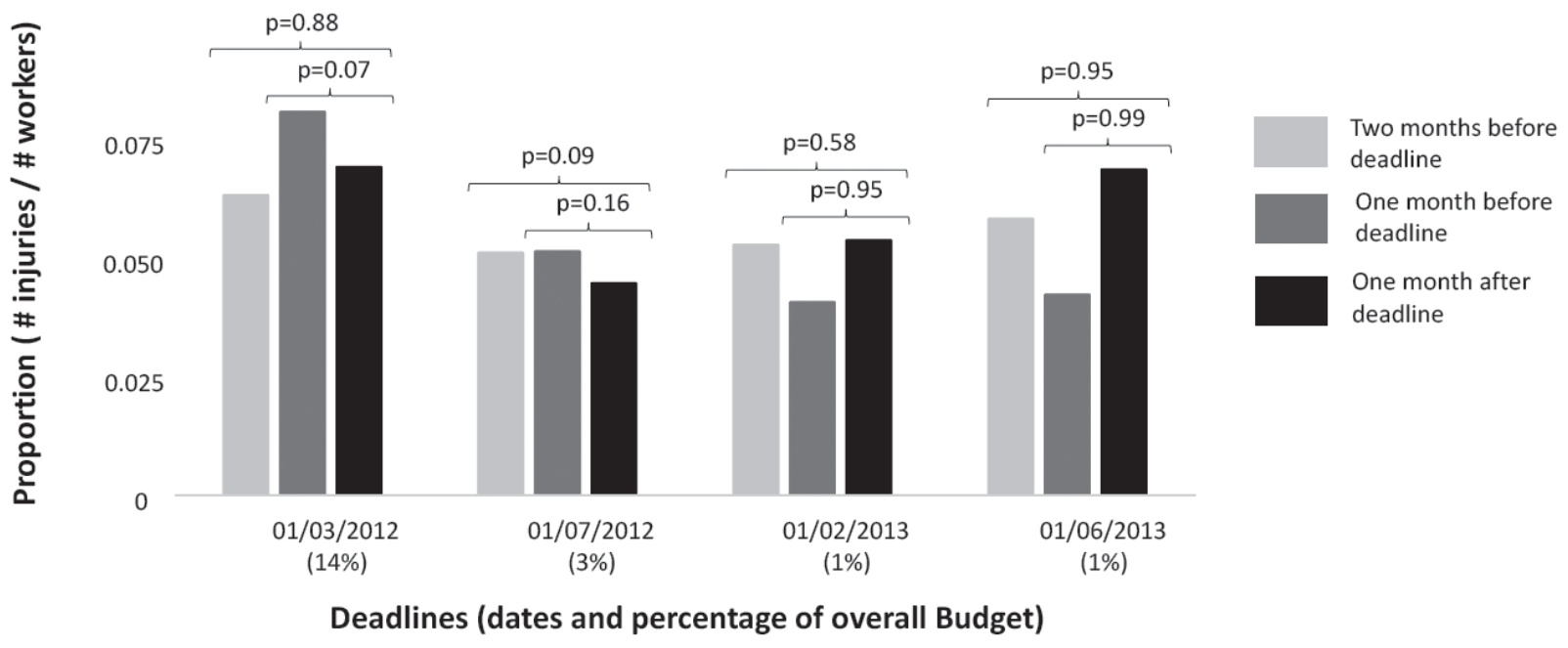

Figure 1. Occurrence of occupational injuries during the months before and after important deadlines on a construction project.

\section{Discussion}

These findings suggest that injuries increase significantly prior to important financial contractual milestone. The necessity to perform more activities leads to the involvement of more workers, with a corresponding increase in work hours and overtime. This phenomenon at work process appears to act as a trigger that increases the incidence of occupational injuries. Thus, important contractual milestones could increase human errors because in previous periods the job demands are higher than in other moments. Note that contractual milestones act as distal determinant whereas human errors are proximal determinants of injuries ${ }^{15}$. The "student syndrome" as effect contextual seems to be present in construction companies, becoming the macro expression of the procrastination of those responsible for organizing construction activities. Maybe, this may increase the labor stress of workers, which would lead to increased insecure acts and injuries. These findings show that it is important for construction companies to plan better the timelines of their activities so that they do not find themselves needing to increase unsafe work before important contractual deadlines.

\section{References}

1. Bertazzi PA. Industrial disasters and epidemiology. A review of recent experiences. Scand J Work Environ Health. 1989; 15: 85-100. https://www. jstor.org/stable/40965631.

2. Brogmus GE. Day of the week lost time occupational injury trends in the US by gender and industry and their implications for work scheduling. Ergonomics. 2007; 50: 446-474. doi: https://doi. org/10.1080/00140130601133826.

3. Amiri M, Ardeshir A, Fazel Zarandi MH. Riskbased analysis of construction accidents in Iran during 2007-2011-meta analyze study. Iran J Public Health. 2014; 43: 507-522.

4. Shao B, Hu Z, Liu Q, Chen S, He W. Fatal accident patterns of building construction activities in China. Saf Sci. 2019; 112: 130-141. doi: http://10.1016/j. ssci.2018.07.019.

5. Camino López MA, Fontaneda I, González Alcántara OJ, Ritzel DO. The special severity of occupational accidents in the afternoon: "The lunch effect". Accid Anal Prev 2011; 43: 1104-1116. doi: https://doi.org/10.1016/j. aap.2010.12.019. 
6. Eliason M, Ohlson H. Living to save taxes. Econ Lett. 2008; 100: 340-343. doi: http://10.1016/j. econlet.2008.02.034.

7. Shimizu M, Pelham B. Postponing a date with the grim reaper: ceremonial events and mortality. Basic Appl Soc Psychol. 2008; 30: 36-45.

8. Yang CH, Huang YT, Janes C, Lin KC, Lu TH. Belief in ghost month can help prevent drowning deaths: a natural experiment on the effects of cultural beliefs on risky behaviours. Soc Sci Med. 2008; 66: 19901998. doi: 10.1016/j.socscimed.2008.01.014.

9. Wilches-Gutiérrez JL, Arenas-Monsalve LM, PauloMaya A, Peláez-Ballestas I, Idrovo AJ. A "beautiful death": Mortality, death and holidays in a Mexican municipality. Soc Sci Med. 2012; 74(5): 775-782. doi: 10.1016/j.socscimed.2011.11.018.

10. Wilbert-Lampen U, Leistner D, Greven S, Pohl T, Sper S, Völker C, et al. Cardiovascular events during World Cup soccer. N Engl J Med. 2008; 358: 475-483. doi: 10.1056/NEJMoa0707427.

11. Lloyd B, Matthews S, Livingston M, Jayasekara $\mathrm{H}$, Smith K. Alcohol intoxication in the context of major public holidays, sporting and social events: a time-series analysis in Melbourne, Australia, 20002009. Addiction 2013; 108: 701-709. doi: 10.1111/ add.12041.

12. Fernández-Niño JA, Astudillo-García CI, BojorquezChapela I, Morales-Carmona E, Montoya-Rodriguez AA, Palacio-Mejia LS. The Mexican cycle of suicide: a national analysis of seasonality, 2000-2013. PLoS One. 2016; 11(1): e0146495. doi: 10.1371/journal. pone. 0146495 .

13. Leach LP. Critical chain project management improves project performance. Proj Manag J. 1999; 30: 39-51. doi: https://doi.org/10.1177/ 875697289903000207.

14. Ariely D, Wertenbroch K. Procrastination, deadlines, and performance: self-control by precommitment. Psychol Sci. 2002; 13: 219-224. doi: https://doi. org/10.1111/1467-9280.00441.

15. Wahrendorf M, Siegrist J. Proximal and distal determinants of stressful work: framework and analysis of retrospective European data. BMC Public Health. 2014; 14: 849. 